\title{
Biodiversity Protection in Private Forests: PES Schemes, Institutions and Prosocial Behavior
}

\author{
Jens Abildtrup ${ }^{1}$, Anne Stenger ${ }^{2, *}$, Francis de Morogues ${ }^{3}$, Philippe Polomé ${ }^{4} \oplus$, Marieke Blondet ${ }^{5}$ \\ and Claude Michel ${ }^{6}$
}

check for updates

Citation: Abildtrup, J.; Stenger, A.; de Morogues, F.; Polomé, P.; Blondet, M.; Michel, C. Biodiversity Protection in Private Forests: PES Schemes, Institutions and Prosocial Behavior. Forests 2021,12, 1241. https:// doi.org/10.3390/f12091241

Academic Editor: Jessica Leahy

Received: 21 June 2021

Accepted: 26 August 2021

Published: 14 September 2021

Publisher's Note: MDPI stays neutral with regard to jurisdictional claims in published maps and institutional affiliations.

Copyright: (c) 2021 by the authors. Licensee MDPI, Basel, Switzerland. This article is an open access article distributed under the terms and conditions of the Creative Commons Attribution (CC BY) license (https:// creativecommons.org/licenses/by/ $4.0 /)$.
INRAE, BETA-Université de Lorraine, 54000 Nancy, France; jens.abildtrup@inrae.fr

2 INRAE, BETA-Université de Strasbourg, 67081 Strasbourg, France

FCBA, 38610 Grenoble, France; francis.DE.MOROGUES@fcba.fr

Faculty of Economics and Management, Université de Lyon, 69007 Lyon, France; polome@gate.cnrs.fr

AgroParisTech, 54000 Nancy, France; marieke.blondet@agroparistech.fr

6 Parc du Ballon des Vosges, 68140 Munster, France; c.michel@parc-ballons-vosges.fr

* Correspondence: anne.stenger-letheux@inrae.fr

\begin{abstract}
The overall research question addresses the effectiveness of incentive mechanisms in poli -cies that enhance private forest owners' biodiversity protection. In particular, the paper focuses on the link between forest owners' motivations, incentives, and institutions, and questions the incentives of the current biodiversity protection policies. Our hypothesis is that the purely monetary nature of the incentives can cause a "crowding out effect", i.e., forest owners may reduce their voluntary contribution to biodiversity protection that is driven by prosocial motivations (altruism, self-image, etc.). With this in mind, as well as the knowledge acquired via this project about forest owners' motivations, we looked for the most effective combinations of "incentive mechanisms" (monetary and non-monetary) and "institutions" (national and local authorities, NGOs, etc.) to encourage forest owners to adopt biodiversity protection measures in their forests.
\end{abstract}

Keywords: PES; prosocial behavior; crowding out; biodiversity; choice experiment; forest owners

\section{Introduction}

In this paper we empirically analyze designs of voluntary biodiversity protection schemes. In particular, we investigate whether or not institutions, prosocial behavior, and potential crowding out may influence participation in protection schemes. Our research is based on a survey of private forest owners in France consisting of a discrete choice experiment, in line with [1].

Forests are home to $80 \%$ of the earth's biodiversity, and much biodiversity is found on private land, including private forests. Conservation of biodiversity thus requires the design of policies that influence foresters' decisions [2]. Biodiversity is central to forest ecosystem services and there is still a great need to implement better management and practices, especially in forests and outside protected areas [3]. In [4], the authors observed that monetary tools are the most frequently used solution in a review of studies on Mediterranean agroecosystems. However, they argue that social and biophysical attributes are important as well when considering cases in which farmers have to be incentivized to supply ecosystem services. Institutions, regulation, and political aspects like law enforcement are also important. For example, in [5], the authors reported that the main constraints that impede an effective monitoring of biodiversity in Greece are institutional and political.

Voluntary contracts with forest owners have been suggested as one approach to encouraging private forest owners to consider biodiversity protection in their management, and the payment for ecosystem services (PES) schemes has recently been the focus of a large number of papers [6-9]. In France, private forest owners with land in Natura 
2000 zones are offered a contract that defines protection measures to be implemented in return for economic compensation [10]. However, these contracts have met with relatively limited success.

It has been suggested that the limited success of PES measures could be explained by the fact that forest owners' management motivations are not just limited to profitmaximization alone [11,12]. Consequently, the literature on intrinsic motivations and social norms should be mobilized [13,14]. Intrinsic motivations are related to a person's deep desire to perform a task, regardless of monetary compensation. The introduction of monetary rewards (extrinsic motivations) can weaken individuals' intrinsic motivations by diverting them from their initial willingness to perform the intended task. This effect is referred to as 'eviction' or a 'crowding out' effect, suggesting that people with high intrinsic motivations can lose their motivations 'to do' for others or for the common good ('pro-social behavior') when extrinsic incentives like money are offered to them [15]. Extrinsic incentives can be interpreted as a way to control them and to divert them from their intrinsic motivations, e.g., altruism, warm-glow [16], fairness, and reciprocity [17,18]. Extrinsic incentives are implemented through formal (regulation) or informal (moral suasion) institutions, e.g., as in [19]. These last authors, as well as [20,21], tested the role of institutions or regulation implementation on agents' motivations. They all concluded that formal or informal institutions can change the individual contribution to public goods in a significant way, diminishing intrinsic motivations and providing some evidence about the necessity to deeply think about the way public policies and institutions can motivate individuals. In a very recent paper [22], the necessity of implementing policy reforms is addressed in order to obtain an increase in biodiversity protection in Sweden, nevertheless casting doubts on the willingness of Swedish family forest owners to voluntarily adopt these same measures.

This raises the question of the way to design PES schemes that account for landowners who may have intrinsic motivations for biodiversity protection [23]. This question is important for two reasons. First, are forest owners going to stop protecting biodiversity if they are offered a contract with financial compensation? Second, if forest owners already protect biodiversity, will they be willing to accept a contract with financial compensation? Whereas it may be acceptable from an equity point of view for forest managers to obtain compensation for conservation measures that they would have undertaken even without any economic compensation, this would add to the (public) conservation budget without any additional protection. Furthermore, accounting for intrinsic behavior and social norms may also reduce the need to enforce protection measures, which is particularly important in certain situations where asymmetric information between landowners and regulators is important [24].

Crowding out has been analyzed with respect to voluntary forest contracts in Finland [25], showing that forest owners with an altruistic approach to forest management were less likely to have entered into a contract. Prosocial behavior has, for example, been analyzed in a developing country context [26]. In [24], they analyzed Cambodian PES schemes and participants' motivations. They concluded that a program with monetary compensations may have consequences on the long-term effectiveness of the program since individuals who emphasized money-related values reported significantly more often that they would break conservation rules after an eventual end of payments.

In [23], the authors reviewed the empirical evidence of crowding out in the conservation literature and concluded that it is crucial to assess existing intrinsic motivations and expected changes in people's motivational structures prior to the large-scale implementation of economic instruments. They divided the methods for assessing motivation crowding effects into framed field experiments, natural field experiments and natural experiments. However, as in [1], we empirically tested the potential scheme design in a stated discrete choice model (DCE). DCEs have become a popular way to test different PES scheme designs [2,27-30]. We contribute to the literature with an assessment of the role of the institutional framework for the commitment of forest owners to biodiversity 
conservation based on a sample of forest owners in the "Ballon des Vosges" Regional Nature Park (France). Furthermore, we show how a DCE can be designed to identify the interaction between program attributes and prosocial motivation through the design of attributes and split samples. Finally, we show that the effects of program attributes that target the owners' prosocial behavior are heterogeneous over the sample.

The DCE approach is developed in Section 2. The results are then presented and discussed in Sections 3 and 4, followed by a conclusion and some public policy recommendations in Section 5.

\section{Data and Methodology}

\subsection{The Study Area}

The present study was carried out in a regional nature park, the Ballon des Vosges, located in northeastern France. The study is part of a larger project focused on biodiversity conservation in private forests. The study population consists of private forest owners with at least one plot of land larger than 0.05 ha in the Ballon des Vosges Regional Nature Park. This implies that public forests, properties with a surface area of less than 0.05 ha, and properties belonging to forestry groups or private companies, etc. are not included in the survey. Table 1 shows the distribution of the forest sizes in the park, indicating that the large majority of owners have very small forests of less than 10 ha. The forest covers about two-thirds of the park area $\left(2921 \mathrm{~km}^{2}\right)$. The forests are dominated by mixed forest stands but there are also mono-species coniferous and broadleaf stands. A large share of the owners in the park are eligible for NATURA 2000 contracts. However, only very few have a contract or have signed a charter [31].

Table 1. The number of individually-owned plots broken down by size within the Ballon des Vosges Regional Nature Park.

\begin{tabular}{ccccccc}
\hline Size & $\mathbf{0 . 0 5}-\mathbf{0 . 7 4}$ ha & $\mathbf{0 . 7 5 - 1 . 9 9}$ ha & $\mathbf{2 - 3 . 9 9}$ ha & $\mathbf{4 - 9 . 9 9}$ ha & $\geq \mathbf{1 0}$ ha & Total \\
\hline Number & 20,443 & 5894 & 2507 & 1475 & 660 & 30,979 \\
$\%$ & $66 \%$ & $19 \%$ & $8 \%$ & $5 \%$ & $2 \%$ & - \\
\hline
\end{tabular}

\subsection{The Discrete Choice Experiment}

A discrete choice experiment was used to reveal forest owners' preferences for an alternative commitment to nature protection. The first step in designing a DCE is to define the alternatives and the attributes. It is important that the selected attributes for the commitment alternatives allow the relevant assumptions to be tested, and that the attributes are relevant to the forest owners' choices. An important contribution to the definition of attributes comes from the analysis of our collaborative workshop (World Café) that was held with the stakeholders. In Figure 1 below, we report the selected attributes and their definition.

Since the main objective of this study was to identify the institutional factors that influence commitment, it was decided not to let protection action as such be an attribute. The objective was not to estimate the opportunity costs of forest owners to implement different protection measures but, instead, to estimate how an institutional factor would influence the probability of commitment and how these factors can influence the demand for monetary compensation. However, in order to assess the impact of institutional factors on the decision to initiate it, it was necessary to define relevant and applicable protective measures for all forest owners, from the smallest plot to the largest. In addition, these protective measures should be easy to explain in a questionnaire. Furthermore, by proposing two protection measures and leaving the choice to the owner, we reduce the risk that a forest owner will not accept any commitment and therefore not provide any information on institutional preferences. 


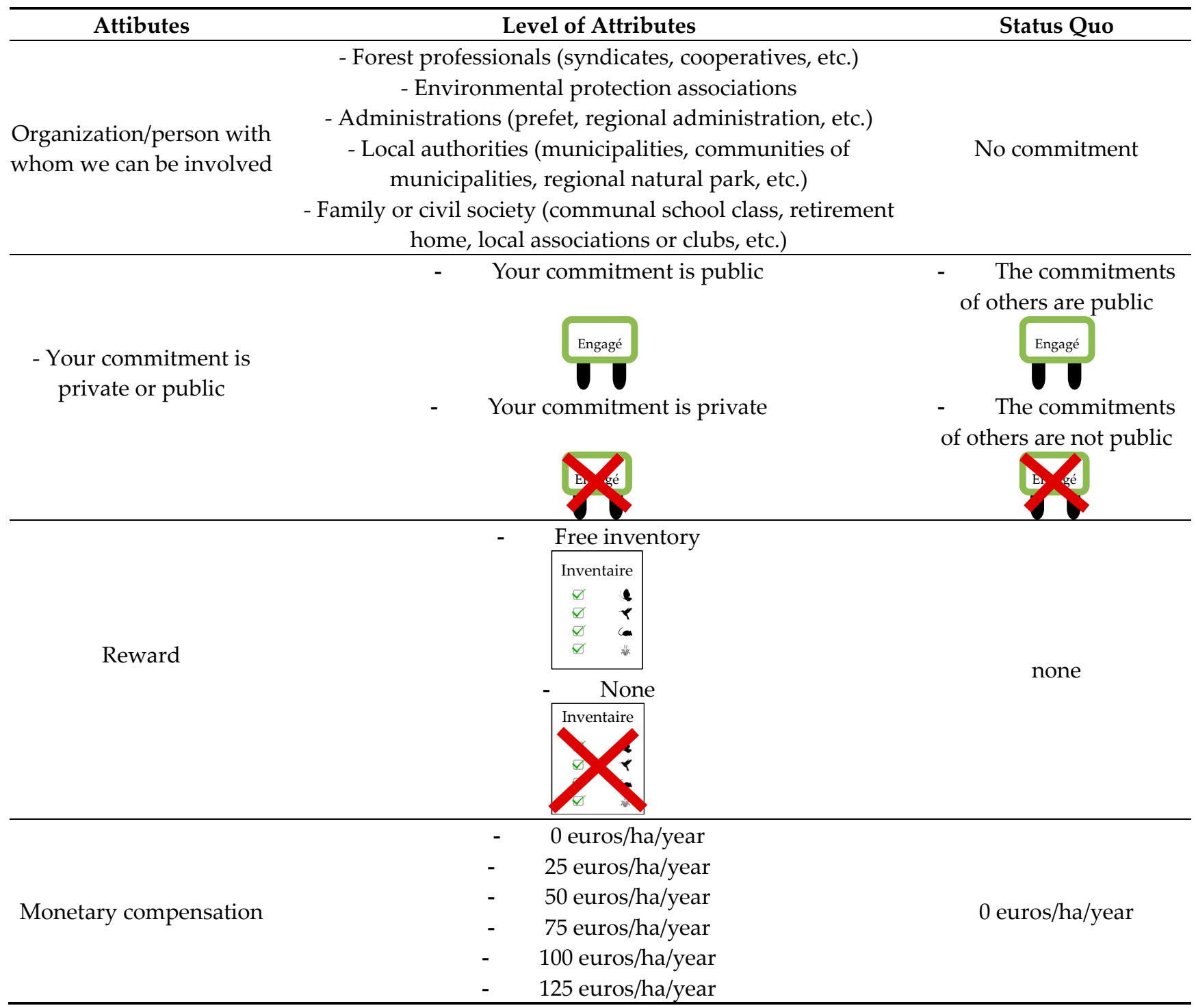

Figure 1. Attributes and their levels in the choice experiment.

It was decided to propose two protection actions:

- Leave more dead wood on the ground or standing (diameter $>30 \mathrm{~cm}$ ) than you do today during a harvest (minimum: 5 trees per hectare);

- Keep more very large living trees (more than $70 \mathrm{~cm}$ in diameter) than you do today (minimum: 2 trees per hectare).

Before the experiment, respondents were asked which of these two biodiversity protection actions is most relevant to their forest. The most relevant was therefore used as a protective measure in all subsequent commitment choices. The hypothesis is that the impact of institutional factors does not depend on which of these two measures is chosen by forest owners.

The first attribute is the organization in which the forest owner is involved (see Table 1). Four alternatives were chosen, mainly based on the inspiration of our World Café. The second attribute indicates whether the commitment is public or private. If a commitment is public, it will, e.g., be published on the website of the Ballon des Vosges Regional Nature Park and/or on a panel installed at the entrance to the forest, explaining the commitment made. If the commitment is not public, it remains anonymous to the general public and only the organization in which the owner is involved is aware. The third attribute indicates whether the commitment provides access to a non-monetary incentive defined as a reward 
through a free biodiversity inventory or a calculation of the biodiversity index (PBI) of their plot. Finally, monetary compensation has been included. This is defined as an annual compensation paid per hectare by the government (0-125 euros). However, a monetary incentive was not included if the commitment was with the family or civil society because it was not considered credible.

The second step of our choice experiment consists in defining combinations of alternative commitments and their combination in choice situations. We decided to let each respondent participate in two DCEs. The first DCE did not include the monetary incentive attribute (see Figure 2a), while the second DCE included monetary and non-monetary incentives (Figure 2b).

If the respondent knows that a commitment could potentially have monetary compensation, he or she will be less reluctant to accept a commitment without monetary compensation. To test this hypothesis, we let the respondent first choose commitments without mentioning anything about potential monetary compensation. The first part included 12 choice situations and the second part 16 choice situations. A total of 28 choices was considered too numerous for an individual to agree to complete the questionnaire. Two versions of the questionnaire were then developed with six and eight choice situations assigned to each of the two versions, and then randomly distributed to the respondents. The combination of attribute levels is done using a so-called d-efficient model that seeks to maximize the information that can be derived from respondents' choices and thus reduces the sample size required to estimate the underlying decision model [32]. A pre-test of the design was carried out on a simulated dataset to verify that it would be possible to test the hypotheses.

\begin{tabular}{|c|c|c|c|c|c|}
\hline Choice 1 & No Commitment & $\begin{array}{c}\text { Commitment } \\
1\end{array}$ & $\begin{array}{c}\text { Commitment } \\
2\end{array}$ & $\begin{array}{c}\text { Commitment } \\
3\end{array}$ & $\begin{array}{c}\text { Commitment } \\
4\end{array}$ \\
\hline $\begin{array}{l}\text { Organization/ } \\
\text { person involved } \\
\text { with }\end{array}$ & & $\begin{array}{l}\text { Commitment } \\
\text { with forest } \\
\text { professionals }\end{array}$ & $\begin{array}{l}\text { Commitment } \\
\text { with } \\
\text { administration }\end{array}$ & $\begin{array}{l}\text { Commitment } \\
\text { with } \\
\text { local } \\
\text { collectives }\end{array}$ & $\begin{array}{c}\text { Commitment } \\
\text { with } \\
\text { family/civil } \\
\text { society }\end{array}$ \\
\hline $\begin{array}{l}\text { Commitment is } \\
\text { public or private }\end{array}$ & $\begin{array}{l}\text { The commitment } \\
\text { of the others are } \\
\text { public }\end{array}$ & $\begin{array}{c}\text { Your } \\
\text { commitment is } \\
\text { public }\end{array}$ & $\begin{array}{c}\text { Your } \\
\text { commitment is } \\
\text { private }\end{array}$ & $\begin{array}{l}\text { Engagé } \\
\text { Commitment is } \\
\text { public }\end{array}$ & $\begin{array}{l}\text { Your } \\
\text { commitment is } \\
\text { private }\end{array}$ \\
\hline Compensation & & $\begin{array}{l}\text { No free } \\
\text { inventory }\end{array}$ & 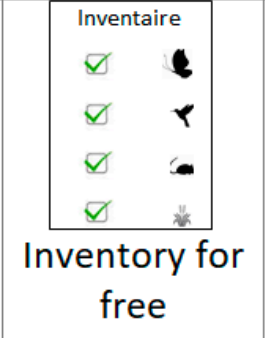 & 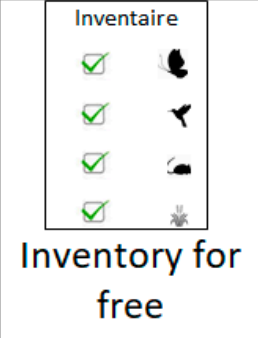 & $\begin{array}{c} \\
\text { No free } \\
\text { inventory }\end{array}$ \\
\hline Choose $\rightarrow$ & $\square$ & $\square$ & $\square$ & $\square$ & $\square$ \\
\hline
\end{tabular}

(a)

Figure 2. Cont. 


\begin{tabular}{|c|c|c|c|c|c|}
\hline Choice 9 & $\begin{array}{c}\text { No } \\
\text { Commitment }\end{array}$ & $\begin{array}{c}\text { Commitment } \\
1\end{array}$ & $\begin{array}{c}\text { Commitment } \\
2\end{array}$ & $\begin{array}{c}\text { Commitment } \\
3\end{array}$ & $\begin{array}{c}\text { Commitment } \\
4\end{array}$ \\
\hline $\begin{array}{c}\text { Organization/ } \\
\text { person involved with }\end{array}$ & & $\begin{array}{c}\text { Commitment } \\
\text { with forest } \\
\text { professionals }\end{array}$ & $\begin{array}{l}\text { Commitment } \\
\text { with } \\
\text { administration }\end{array}$ & $\begin{array}{l}\text { Commitment } \\
\text { with } \\
\text { local } \\
\text { collectives }\end{array}$ & $\begin{array}{l}\text { Commitment } \\
\text { with } \\
\text { family/civil } \\
\text { society }\end{array}$ \\
\hline $\begin{array}{l}\text { Commitment is } \\
\text { public or private }\end{array}$ & $\begin{array}{c}\text { The } \\
\text { commitments } \\
\text { of others are } \\
\text { private }\end{array}$ & $\begin{array}{c}\text { Your } \\
\text { commitment is } \\
\text { public }\end{array}$ & $\begin{array}{l}\text { Your } \\
\text { commitment } \\
\text { is private }\end{array}$ & $\begin{array}{l}\text { Your } \\
\text { commitment } \\
\text { is private }\end{array}$ & $\begin{array}{c}\text { Your } \\
\text { commitment is } \\
\text { private }\end{array}$ \\
\hline Compensation & & 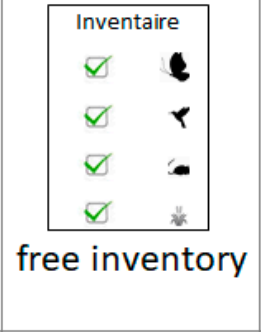 & 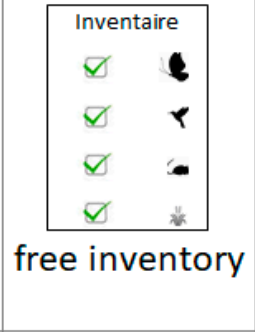 & 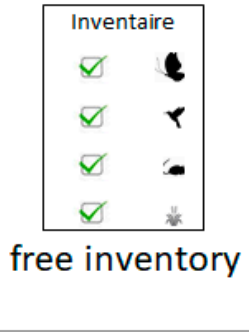 & $\begin{array}{c}\square \\
\text { No free } \\
\text { inventory }\end{array}$ \\
\hline $\begin{array}{c}\text { Monetary } \\
\text { compensation }\end{array}$ & & $\begin{array}{c}75 \\
\text { euros/ha/year }\end{array}$ & $\begin{array}{c}100 \\
\text { euros/ha/Year }\end{array}$ & $\begin{array}{l}50 \\
\text { euros/ha/Year }\end{array}$ & $\begin{array}{c}0 \\
\text { euros/ha/Year }\end{array}$ \\
\hline Choose $\rightarrow$ & $\square$ & $\square$ & $\square$ & $\square$ & $\square$ \\
\hline
\end{tabular}

(b)

Figure 2. (a) Choice situation without monetary compensation; (b) Choice with monetary compensation.

The third step consists in formulating an introduction to the choice experiment and follow-up questions. A crucial element of a choice experience is to explain the choice context and the alternatives. The questionnaire included a section presenting the attributes of the commitments. It then explained that the commitment would last at least 20 years, but they could cancel the commitment before if they repaid any reward they may have received. It was also explained that if the property changed ownership, the new owner would be free to choose whether or not to keep the contract. The option to be able to end the contract with ownership change is based on initial discussions that revealed that forest owners were afraid to commit subsequent owners, typically their children. Half of the respondents, selected randomly, were told that they would be the first in their municipality to have one of the proposed commitments, and the other half that they should imagine that half of the forest owners in their municipality have already committed to one of the proposed commitments. Respondents were reminded that they could always choose "no commitment" if they found none of the proposed commitments attractive. Following these responses, there were some follow-up questions where it was asked if the respondent had taken all of the attributes into account when making their choices. Respondents who did not choose a contract in any of the 14 choices were asked why they did not choose a contract in the follow-up questions.

In addition to the choice experiment, the questionnaire included several other questions that facilitated the interpretation of the results of the choice experiment. For example, we asked direct questions about the organization with which they prefer to interact and why. While the choice experiment makes it possible to estimate how forest owners make trade-offs between different attributes (for example, to estimate how the required monetary 
compensation changes with different organisms), these questions can help explain why forest owners make these trade-offs.

The questionnaire included relatively few questions about the forest and the forest owner since the forest owners interviewed had already participated in a telephone interview and provided this information. The questionnaire was tested within the project group (which included sociologists having carried out qualitative interviews with forest owners) and in face-to-face testing of the questionnaire with forest owners.

The questionnaire was available on the Internet, programmed with LimeSurvey, free software, and hosted by an INRAE server. E-mails were sent to 214 forest owners with two reminders (postal and telephone). E-mail addresses were obtained by a previous telephone interview where the respondents were asked if they would participate in a follow-up survey. Forest owners who did not complete the Internet-based questionnaire were sent a letter with 14 choice cards from the DCE and told that they would be contacted by telephone. Several days after having received this letter, an interviewer from the company Wood!Up contacted the owners and completed the questionnaire with them. When giving the answers to the choice experiment, owners were asked to have the printed choice card in front of them. This approach allowed us to have 99 usable questionnaires. A comparison of the sample obtained with the breakdown of the respondents' plot size in the telephone survey (Table 2) shows that the sample obtained is not statistically different (Pearson's Chi-Square test: $\mathrm{X} 2=2.7$; $p$-value $=0.60$ ).

Table 2. Comparison of plot sizes in telephone and DCE surveys.

\begin{tabular}{|c|c|c|c|c|c|}
\hline Size Classes & $S$ & $\mathbf{M}$ & $\mathbf{L}$ & $X$ & $\mathbf{X L}$ \\
\hline Area & 0.05 ha- 0.74 ha & 0.75 ha-1.99 ha & 2 ha-3.99 ha & 4 ha-9.99 ha & 10 ha and + \\
\hline $\begin{array}{c}\text { Telephone } \\
\text { interviews (\%) }\end{array}$ & 21.4 & 21.5 & 21.7 & 20.9 & 14.5 \\
\hline DCE survey (\%) & 26.2 & 17.9 & 16.7 & 21.4 & 17.9 \\
\hline
\end{tabular}

\subsection{The Econometric Analysis}

The results from the choice experiment were analyzed using a random utility (profit) model [33]. Utility of contract $j$ for forest owner $i$ is defined in Equation (1): as:

$$
v_{i j}=\beta_{f} x_{f i j}+\beta_{k P} x_{k i j}+\beta_{P} x_{P i j}+\beta_{N M} x_{N M i j}+\beta_{M} x_{M i j}+\beta_{M P} x_{M i j} x_{P i j}+\beta_{N M P} x_{N M i j} x_{P i j}+\varepsilon_{i j}
$$

where:

$x_{f i j}$ : forest protection measure in contract $j$ demanded of forest owner $i$ (will be a vector of dummies; one for each commitment considered, whereas no dummy for choosing "no commitment")

$x_{P i j}: 1$ if contract $j$ is published for forest owner $i ; 0$ otherwise

$x_{M i j}$ : monetary compensation for contract $j$ offered to forest owner $i$

$x_{N M i j}$ : non-monetary compensation for contract $j$ offered to forest owner $i$

$x_{k i j}$ : other contract attributes in contract $j$ offered to forest owner $i$ (institution)

$\varepsilon_{i j}$ : a random term not observed by the researcher

$\beta$ are the parameters to be estimated, i.e., the marginal impact on utility or profit of the different contract characteristics.

The forest owner will choose the contract $j$ that will give the highest utility: $v_{i j}>$ $v_{i l}$ where $k \neq l$.

Test of crowding out: If the parameter of interaction term $\beta_{M P}$ in (1) is negative, then the utility of money compensation is negative with a published contract (because money paid will show the forest owner as a greedy person). Furthermore, our hypothesis is that non-monetary compensation will not imply crowding out, i.e., $\beta_{N M P}=0$. 
The sign of the $\beta_{P}$ is not clear from theory. People will be more likely to enter into a contract if they think that it will contribute to a positive social image. However, a public contract will reduce the possibility of moral hazard since all visitors to the forest may observe if the owner complies with the contract. By estimating an econometrical model that allows for preference heterogeneity, e.g., a latent class model, we may be able to identify groups of owners that are likely to enter into a contract if they are public, whereas another group is less likely to enter into a contract.

Crowding out associated with owners with prosocial behavior determined by altruistic behavior and who are not influenced by others' views of them can be identified as a test of linearity of the marginal utility of income (compensation), i.e., a dummy variable which takes the value of one when the payment is zero. If this is positive and significantly different from zero, it can be deduced that there is a disutility of being economically compensated. However, this is a rather weak test as it is based on the assumption that utility is linear as a function of income.

\section{Results}

The socio-demographics of the forest owners participating in the choice experiment are described in Table 3. Two thirds of the forest owners are male, and the large majority of the forest owners are over 60 years old. Consequently, retirement is the most common professional status. There are very few foresters in the sample. This latter result is of course linked to the very small size of the plots. This also implies that the share of income that comes from their forest is very low. Inheritance was most often cited as the principal objective of their forest management, followed by timber production. This result corresponds to the answer to the question of whether or not they intend to bequeath their forest. More than half of the forest owners consider bequeathing their forest.

First, we estimated respondents' preferences for different institutional factors by applying the conditional logit [33]. In the tables below, the parameters represent the marginal utilities related to the attributes. A positive parameter of an attribute implies that this attribute contributes positively to the utility obtained through commitment and increases the probability that a forest owner will commit. The attributes are defined as dummy variables except for the monetary attribute that is modeled as a continuous variable. For the institutional attribute, we have included four dummies, one for each institution, whereas the reference (dummy variable not included) is choosing "no commitment". This implies that the parameters of the four institutional dummy variables express the marginal utility of a commitment with the institutions relative to choosing "no commitment". Therefore, the marginal utilities of the different institutions are confused with the marginal utility of commitment itself. However, it is the difference between marginal utilities among the institutions that is of primary interest to us. Since the dummy variables for institutions also imply a commitment, we can expect their coefficients to have a negative sign because a commitment implies an opportunity cost for the forest owner to leave dead wood or maintain large trees in forests that could otherwise be harvested. 
Table 3. Socio-demographic variables.

\begin{tabular}{|c|c|}
\hline & $\%$ \\
\hline \multicolumn{2}{|l|}{ Gender } \\
\hline Male & 73 \\
\hline Female & 27 \\
\hline \multicolumn{2}{|l|}{ Age } \\
\hline$>30$ & 1 \\
\hline $30-39$ & 2 \\
\hline $40-49$ & 7 \\
\hline $50-59$ & 19 \\
\hline $60-69$ & 31 \\
\hline $70-79$ & 25 \\
\hline $80+$ & 14 \\
\hline \multicolumn{2}{|l|}{ Social-professional category } \\
\hline Forester & 3 \\
\hline Farmer & 6 \\
\hline Merchant, tradesman, business manager & 4 \\
\hline Executive, highly educated professional & 3 \\
\hline Intermediate occupation (nurse, & 2 \\
\hline technician, etc.) & \\
\hline Salaried employee & 6 \\
\hline Laborer & 1 \\
\hline Retiree & 65 \\
\hline Out of the labor force & 1 \\
\hline Other & 8 \\
\hline \multicolumn{2}{|l|}{ Share of income from forestry } \\
\hline An important part & 7 \\
\hline A small part & 23 \\
\hline Zero or almost zero & 70 \\
\hline \multicolumn{2}{|l|}{ Do you intend to bequeath your forest? } \\
\hline No & 16 \\
\hline Yes & 54 \\
\hline Have not studied the issue & 30 \\
\hline \multicolumn{2}{|l|}{ Principal management objective } \\
\hline Inheritance & 45 \\
\hline Timber production & 29 \\
\hline Other & 15 \\
\hline $\begin{array}{l}\text { Preservation of the environment } \\
\text { (biodiversity, climate, water quality, etc.) }\end{array}$ & 6 \\
\hline Hunting activities & 3 \\
\hline Outdoor recreation & 2 \\
\hline
\end{tabular}

3.1. Result: The Type of Institution Plays a Role in the Decision (Probability) of the Owner's Commitment

Table 4 below provides estimates of a first model for all respondents. The negative sign is confirmed for all institutional attributes except for "Forest Professionals". In the latter case, the parameter is positive, indicating that, on average, forest owners do not consider that involving themselves with forest professionals is a cost to them, but this parameter is not significant. Nevertheless, institutions other than "Forest Professionals" are less preferable, and therefore reduce the probability of commitment. The hierarchy is "Local authorities", "Family or civil society", followed by "Administrations". 
Table 4. Estimation of "conditional Logit" for all responses.

\begin{tabular}{|c|c|c|c|c|}
\hline Attributes & Parameter & S.D. & $\mathbf{z}$ & Prob \\
\hline Forest professionals ( $=1$ if commitment with them) & 0.112 & 0.087 & 1.280 & 0.199 \\
\hline Administrations ( $=1$ if commitment with administrations) & -2.221 & 0.154 & -14.400 & 0.000 \\
\hline Local authorities (=1 if commitment with them) & -0.794 & 0.101 & -7.880 & 0.000 \\
\hline Family or civil society (=1 if commitment with them) & -1.788 & 0.129 & -13.850 & 0.000 \\
\hline Public commitment (=1 if public) & 0.082 & 0.064 & 1.270 & 0.203 \\
\hline Rewards with an inventory (=1 if rewarded with an inventory) & 0.160 & 0.082 & 1.950 & 0.051 \\
\hline Monetary compensation (euros/ha/year) & 0.002 & 0.001 & 1.940 & 0.053 \\
\hline $\mathrm{N}=99 ;$ choices $=1385 ;$ pseudo $\mathrm{R}=0.18$ & & & & \\
\hline
\end{tabular}

The other results show that, on average, making a public commitment is not statistically significant, while monetary and non-monetary compensation has a significant positive effect but only at a $10 \%$ significance level.

The strong preferences for making commitments with forestry professionals or environmental associations are confirmed by an initial question in the survey where we asked the respondents to rank the institutions with respect to those they would prefer to make a commitment to if they had to. A total of $64 \%$ rated" Forest professionals" the highest. "Administrations" was only chosen by $4 \%$ of the respondents. When asked about their motivation for choosing an institution as the most preferable, confidence was most often given as a reason for choosing "Forest professionals" and "Family or civil society". Knowing the forest better was the reason most often given for choosing "Local authorities" (Table 5).

Table 5. The preferred institute for commitment and the reason for this choice. More than one reason could be given and it was not mandatory to choose one of the proposed reasons.

\begin{tabular}{|c|c|c|c|c|}
\hline & "Forest Professionals" & "Administration" & $\begin{array}{c}\text { "Local } \\
\text { Authorities" }\end{array}$ & $\begin{array}{c}\text { "Family or Civil } \\
\text { Society" }\end{array}$ \\
\hline & $\%$ & $\%$ & $\%$ & $\%$ \\
\hline $\begin{array}{l}\text { Forest owners' chosen } \\
\text { preferred institution }\end{array}$ & 64 & 4 & 17 & 14 \\
\hline \multicolumn{5}{|l|}{ Reasons: } \\
\hline I have more confidence in & 73 & 0 & 50 & 54 \\
\hline I already work with & 54 & 25 & 19 & 31 \\
\hline Knows my forest better & 36 & 25 & 63 & 15 \\
\hline Are less bureaucratic & 19 & 0 & 6 & 15 \\
\hline Other & 2 & 25 & 6 & 0 \\
\hline
\end{tabular}

We can wonder why the respondents have a positive utility of making a commitment to "Forest professionals", even though we expect that implementing the commitment will generate costs for the owner. To better understand the forest owners' views on biodiversity protection, we let them evaluate four statements about protecting biodiversity in forests (Table 6). First, we learned that more than half of the forest owners do not agree with the statement that the protection of biodiversity is costly for the forest owner. Most owners also declare that the majority of forest owners already protect biodiversity without being paid for it. A very large majority of the owners think it is a moral obligation to protect biodiversity. However, this does not exclude the $51 \%$ who totally or somewhat agree that society should pay landowners for biodiversity protection. To conclude, it may not be surprising that we have forest owners who do not ask for economic compensation in exchange for a commitment, reflected in the statistically non-significant parameter on commitment with forestry professionals or environmental associations. Of course, it should be borne in mind that the results in Table 6 are based on the owners' declarations and we had no opportunity to verify their actual management in the field. 
Table 6. The interviewed forest owners' views on biodiversity protection in the forest.

\begin{tabular}{|c|c|c|c|c|c|}
\hline Question & $\begin{array}{c}\text { Totally } \\
\text { Agree } \\
\%\end{array}$ & $\begin{array}{c}\text { Somewhat } \\
\text { Agree } \\
\%\end{array}$ & $\begin{array}{c}\text { Rather } \\
\text { Disagree } \\
\%\end{array}$ & $\begin{array}{c}\text { Strongly } \\
\text { Disagree } \\
\%\end{array}$ & $\begin{array}{c}\text { I Don't } \\
\text { Know } \\
\%\end{array}$ \\
\hline Protecting biodiversity in a forest is costly for the owner & 7 & 19 & 35 & 27 & 12 \\
\hline $\begin{array}{l}\text { Most private forest owners voluntarily protect nature and } \\
\text { biodiversity in their forests without being paid }\end{array}$ & 30 & 41 & 14 & 5 & 9 \\
\hline $\begin{array}{l}\text { The protection of nature and biodiversity in the forest is a } \\
\text { moral obligation for the forest owner }\end{array}$ & 59 & 34 & 4 & 2 & 1 \\
\hline $\begin{array}{l}\text { Society should not pay landowners for biodiversity } \\
\text { protection }\end{array}$ & 24 & 27 & 24 & 11 & 14 \\
\hline
\end{tabular}

Among the survey respondents, about $20 \%$ of forest owners will not commit, even with the highest monetary compensation of 125 euros/ha/year for the proposed measures or whether or not to publicize their commitment. After the DCE, we asked the respondents why they had never chosen a commitment. Their responses show that they do not consider it possible to implement the proposed measure in their forest (keeping dead wood or large trees on the plot) or that they did not want to commit themselves ("I wish to remain in control. I do not wish to commit myself") and therefore refuse the measure regardless of the commitment characteristics (Table 7). It can therefore be argued that these owners have not made any trade-offs between the different attributes of the choice experience and are therefore excluded from the statistical analysis. The resulting sample consequently consisted of 78 forest owners.

Table 7. The reasons stated by the 20 forest owners who did not choose any of the proposed commitments in the DCE. Multiple reasons could be given.

\begin{tabular}{lc}
\hline Reason for Not Choosing Commitment in Any of the Choices & Owners \\
\hline I don't think any of the proposed commitments are feasible in my forest & 3 \\
I don't think any of the proposed commitments have a positive impact on & 0 \\
biodiversity in my forest & 0 \\
The explanations are not sufficient to make my choices & 0 \\
The protection of nature and biodiversity is not important & 1 \\
The choices are too complicated & 2 \\
I am already doing something to protect nature and biodiversity in my forest & 0 \\
and do not need to be rewarded & 0 \\
I would need more information on the impact on biodiversity & 1 \\
I'm not sure about the economic benefits; I need to find out & 16 \\
It's too complicated to get involved & 7 \\
I wish to remain in control. I do not wish to commit myself & \\
Other &
\end{tabular}

\subsection{Result: Making a Commitment to "Forest Professionals" without Compensation}

Table 8 shows the results of the same model as the one used in Table 4, but only for forest owners who are considering a commitment. The results confirm the preferences estimated above for the institutions with which to commit: "Forest professionals" are always preferred. This variable is now significant and indicates that there is a positive utility in committing to "Forest professionals" in relation to not having any commitment. Equally significant is the disincentive to commitment if it is done with "Administrations" or "Family or civil society". In addition, we note that non-monetary and monetary compensation is now statistically significant at a $5 \%$ level. 
Table 8. Conditional logit with respondents who have chosen at least once to commit.

\begin{tabular}{|c|c|c|c|c|}
\hline Attributes & Parameter & Standard Error & $\mathbf{z}$ & Prob \\
\hline Forest professionals ( $=1$ if commitment with them) & 1.034 & 0.113 & 9.140 & 0.000 \\
\hline Administrations (=1 if commitment with administrations) & -1.299 & 0.171 & -7.610 & 0.000 \\
\hline Local authorities ( $=1$ if commitment with them) & 0.129 & 0.124 & 1.040 & 0.297 \\
\hline Family or civil society ( $=1$ if commitment with them) & -0.809 & 0.145 & -5.570 & 0.000 \\
\hline Public commitment ( $=1$ if public) & 0.100 & 0.070 & 1.420 & 0.155 \\
\hline Rewards with an inventory ( $=1$ if rewarded with an inventory) & 0.220 & 0.089 & 2.480 & 0.013 \\
\hline Monetary compensation (euros/ha/year) & 0.005 & 0.002 & 2.830 & 0.005 \\
\hline $\mathrm{N}=78 ;$ choices $=1105 ;$ pseudo $\mathrm{R}=0.20$ & & & & \\
\hline
\end{tabular}

3.3. Result: Lowest Willingness-to-Accept to Commit to Forest Professionals, an Administration or the Family

Although our project focuses on modalities that facilitate commitment, i.e., probability of commitment, in Table 9 below, we present the estimated willingness-to-accept in euros/ha/year to commit. They reflect how forest owners, on average, make a trade-off between monetary compensation and other attributes. On average, forest owners would pay a significant positive amount for a commitment with "Forest professionals (222 euros/ha/year), while requiring very significant compensation if the commitment is with "Administrations" (279 euros/ha/year) or "Family or civil society" (174 euros/ha/year). Several interpretations are possible: An expectation of income induced by committing to forest professionals in the form of advice. In addition, we note that forest owners reduce, on average, their claim for compensation by 47 euros/ha/year if they receive a free inventory.

Table 9. Marginal willingness-to-receive according to the attribute.

\begin{tabular}{|c|c|c|c|c|}
\hline Attributes & $\begin{array}{l}\text { Willingness-to-Receive } \\
\text { (euros/ha/an) }\end{array}$ & Standard Error & $\mathbf{z}$ & Prob \\
\hline Forest professionals (=1 if commitment with them) & -222 & 92.82 & -2.39 & 0.02 \\
\hline $\begin{array}{l}\text { Administrations ( }=1 \text { if commitment with } \\
\text { administrations) }\end{array}$ & 279 & 93.42 & 2.98 & 0.00 \\
\hline Local authorities (=1 if commitment with them) & -28 & 32.15 & -0.86 & 0.39 \\
\hline Family or civil society (=1 if commitment with them) & 174 & 66.75 & 2.60 & 0.01 \\
\hline Public commitment & -21 & 16.68 & -1.28 & 0.20 \\
\hline $\begin{array}{l}\text { Being rewarded with an inventory } \\
N=78 ; \text { choices }=1105\end{array}$ & -47 & 22.39 & -2.11 & 0.04 \\
\hline
\end{tabular}

3.4. Result: The Type of Protection Action Proposed Affects the Probability of Commitment: The Large Living Tree Action Is More Favorable to Commitment Than the Increased Presence of Deadwood

In Table 10, we consider whether the probability of committing depends on the action taken to improve biodiversity (dead wood or large trees). This was tested by adding an interaction variable between commitment and a "large trees" dummy variable. The first term, 'commitment', is equal to 1 if there is a commitment, and zero if there is no commitment. The second term is equal to 1 if the forest owner has chosen to implement the "large tree" action. We find this interaction term to be positive and statistically significant. This indicates that owners who have chosen large tree are more likely to commit and require less compensation. This may correspond to a lower opportunity cost for them. However, it is important to note that the measure has been selected by the respondents, i.e., not exogenously given. Therefore, we cannot extrapolate that keeping large trees are less costly than keeping deadwood to the full population of forest owners. 
Table 10. Effect of neighborhood and type of action on the probability of commitment.

\begin{tabular}{|c|c|c|c|c|}
\hline Attributes & Parameter & Standard Error & $\mathbf{z}$ & Prob \\
\hline Forest professionals ( $=1$ if commitment with them) & 0.715 & 0.157 & 4.550 & 0.000 \\
\hline Administrations (=1 if commitment with administrations) & -1.620 & 0.203 & -8.000 & 0.000 \\
\hline Local authorities ( $=1$ if commitment with them) & -0.191 & 0.165 & -1.160 & 0.247 \\
\hline Family or civil society ( $=1$ if commitment with them) & -1.130 & 0.181 & -6.230 & 0.000 \\
\hline Public commitment ( $=1$ if public) & -0.002 & 0.092 & -0.020 & 0.985 \\
\hline Rewards with an inventory ( $=1$ if rewarded with an inventory) & 0.220 & 0.089 & 2.480 & 0.013 \\
\hline Monetary compensation (euros/ha/year) & 0.005 & 0.002 & 2.830 & 0.005 \\
\hline Constant for commitment $\times$ large tree action & 0.447 & 0.172 & 2.600 & 0.009 \\
\hline Constant for commitment $\times$ first in the municipality & 0.190 & 0.177 & 1.070 & 0.285 \\
\hline Public commitment $\times$ first in the municipality & 0.244 & 0.142 & 1.720 & 0.086 \\
\hline $\mathrm{N}=78 ;$ Choices $=1105 ;$ pseudo $\mathrm{R}=0.21$ & & & & \\
\hline
\end{tabular}

3.5. Result: Making Commitments Public Has an Asymmetric Effect: The Commitment of Other Owners in the Neighborhood Does Not Have an Impact on the Probability of Owners to Commit, but Makes It Known That You Are the First to Commit, Yes

Before proceeding with the DCE, respondents were asked to imagine that they could be the first owners in the municipality to commit or that half of the owners in the municipality already had a commitment. Respondents were randomly assigned to one of these two contextual statements. There is no difference between the two treatments. However, we found that asking the respondents to imagine that they are the first to become involved in the municipality has a positive impact if the commitment is public (significant only at the $10 \%$ level). Apparently, if an owner is the first to commit, he/she wants to show it. This result is interesting because it suggests the potential effect of a leader who would be more willing to relay information.

\subsection{Result: Choice Experiment Confirms That Social Norms Do Not Lead to Eviction}

We also tested whether or not the effect of monetary and non-monetary compensation is influenced by making the commitment public by including interaction terms between the compensation attributes and the public commitment dummy variable. These interaction terms are not significant, indicating that social norms do not lead to eviction. This result is consistent with the results of the telephone survey [31].

A potential crowding-out effect due to prosocial behavior determined by altruistic behavior was tested by including a dummy variable that takes the value of 1 when the payment is zero. The dummy variable was not statistically significant (results not shown in this paper), indicating that altruistic behavior does not have an eviction effect. However, it should be stressed that the power of this test was small due to the relatively small sample size.

\subsection{Result: Forest Owners Are Heterogeneous in Their Commitment Decisions}

To characterize the heterogeneity of forest owners' behaviors, we estimated the random utility model with a random parameter logit model [33]. This model assumes that each forest owner has a unique utility function, i.e., that forest owners do not have the same preferences for the institutional factors of a commitment, for example. We estimated the model assuming that the distributions of forest owners' utility parameters are described by normal distributions.

The first part of Table 11 below describes the estimates of the average of these distributions, while the last part describes the standard deviation of these distributions. The results confirm the results of the previous model, i.e., that the mean distributions have the same signs and are significant. In addition, we found that standard deviations of parameter distributions are statistically significant, i.e., preferences are heterogeneous with respect to forest owners. 
Table 11. "Random parameter logit" to take the heterogeneity of forest owners into account.

\begin{tabular}{|c|c|c|c|c|}
\hline Attributes & Parameter & Standard Error & $\mathbf{z}$ & Prob \\
\hline \multicolumn{5}{|l|}{ Mean of the parameter distributions } \\
\hline Forest professionals (=1 if commitment with them) & 1.879 & 0.289 & 6.490 & 0.000 \\
\hline Administrations (= 1 if commitment with administrations) & -3.299 & 0.529 & -6.240 & 0.000 \\
\hline Local authorities ( $=1$ if commitment with them) & -1.094 & 0.337 & -3.250 & 0.001 \\
\hline Family or civil society (=1 if commitment with them) & -1.381 & 0.309 & -4.470 & 0.000 \\
\hline Public commitment (=1 if public) & 0.096 & 0.177 & 0.540 & 0.588 \\
\hline Rewards with an inventory ( $=1$ if rewarded with an inventory)) & 0.470 & 0.186 & 2.520 & 0.012 \\
\hline Monetary compensation (euros/ha/year) & 0.017 & 0.005 & 3.550 & 0.000 \\
\hline \multicolumn{5}{|l|}{ Standard deviations } \\
\hline Forest professionals ( $=1$ if commitment with them) & 3.937 & 0.463 & 8.503 & 0.000 \\
\hline Administrations ( $=1$ if commitment with administrations) & 3.220 & 0.449 & 7.171 & 0.000 \\
\hline Local authorities ( $=1$ if commitment with them) & 2.653 & 0.275 & 9.647 & 0.000 \\
\hline Family or civil society (=1 if commitment with them) & 1.893 & 0.248 & 7.633 & 0.000 \\
\hline Public commitment (=1 if public) & 1.511 & 0.185 & 8.168 & 0.000 \\
\hline Rewards with an inventory (=1 if rewarded with an inventory) & 1.269 & 0.200 & 6.345 & 0.000 \\
\hline Monetary compensation (euros/ha/year) & 0.026 & 0.005 & 5.200 & 0.000 \\
\hline $\mathrm{N}=78 ;$ choices $=1105$ & & & & \\
\hline
\end{tabular}

This heterogeneity is present on all attributes. In fact, the estimate of the standard deviation of all parameters is statistically significant. Moreover, while the mean of the parameter distribution of the public commitment was not significantly different from zero, the highly significant standard deviation implies that it may be significantly positive for one part of the sample but significantly negative for another.

\subsection{Heterogeneity and Identification of Effective Attribute Pairs}

An alternative approach to take heterogeneity into account in the sample is to apply a latent class model. In this model, it is assumed that there are a number of different latent groups of forest owners. The owners of a group have homogeneous preferences, but the preferences vary from one group to another. In Table 12 below, we estimated our model by assuming three different classes given our reduced sample size of 78 respondents with commitment.

All three classes prefer commitment with local authorities or forest professionals over the administration and the civil society. However, for the second class ( $55 \%$ of the sample), we find statistically significant positive effects on utility for committing with the local authorities and the forest professionals (they accept to commit without being compensated). In addition, the presence of compensation, both monetary and non-monetary, has a significant impact on the likelihood of commitment in the second class. Making the commitment public does not have a significant impact on the likelihood of commitment of this group. In the third class ( $3 \%$ of the sample), commitment has a negative and statistically significant impact on utility, regardless of the type of institution. In fact, it can be concluded that they often refuse the adoption unless there is an exception. Monetary compensation is not statistically significant, whereas non-monetary compensation is positive and weakly statistically significant. This shows the usefulness of offering a choice to owners where both modalities of compensation are present. While the first two classes preferentially commit to forest professionals, they differ in preferences for compensation and publicity of the commitment. 
Table 12. "Latent Class" on three classes.

\begin{tabular}{|c|c|c|c|c|}
\hline Attribute & Parameters & Standard Error & $\mathbf{z}$ & Prob \\
\hline \multicolumn{5}{|l|}{ Class 1} \\
\hline Forest professionals ( $=1$ if commitment with them) & 4.926 & 0.681 & 7.240 & 0.000 \\
\hline Administrations ( $=1$ if commitment with administrations) & 0.635 & 0.694 & 0.920 & 0.360 \\
\hline Local authorities ( $=1$ if commitment with them) & -0.366 & 0.792 & -0.460 & 0.644 \\
\hline Family or civil society (=1 if commitment with them) & -0.491 & 0.856 & -0.570 & 0.566 \\
\hline Public commitment (=1 if public) & 2.071 & 0.476 & 4.350 & 0.000 \\
\hline Rewards with an inventory ( $=1$ if rewarded with an inventory) & 0.392 & 0.398 & 0.980 & 0.325 \\
\hline Monetary compensation (euros/ha/year) & 0.018 & 0.010 & 1.880 & 0.061 \\
\hline \multicolumn{5}{|l|}{ Class 2} \\
\hline Forest professionals (=1 if commitment with them) & 1.115 & 0.245 & 4.540 & 0.000 \\
\hline Administrations ( $=1$ if commitment with administrations) & -0.099 & 0.289 & -0.340 & 0.733 \\
\hline Local authorities ( $=1$ if commitment with them) & 1.538 & 0.243 & 6.340 & 0.000 \\
\hline Family or civil society ( $=1$ if commitment with them) & -0.145 & 0.284 & -0.510 & 0.610 \\
\hline Public commitment ( $=1$ if public) & 0.003 & 0.109 & 0.030 & 0.979 \\
\hline Rewards with an inventory ( $=1$ if rewarded with an inventory)) & 0.423 & 0.146 & 2.890 & 0.004 \\
\hline Monetary compensation (euros/ha/year) & 0.012 & 0.003 & 3.670 & 0.000 \\
\hline \multicolumn{5}{|l|}{ Class 3} \\
\hline Forest professionals ( $=1$ if commitment with them) & -1.100 & 0.236 & -4.660 & 0.000 \\
\hline Administrations ( $=1$ if commitment with administrations) & -5.168 & 1.027 & -5.030 & 0.000 \\
\hline Local authorities ( $=1$ if commitment with them) & -2.294 & 0.313 & -7.330 & 0.000 \\
\hline Family or civil society (=1 if commitment with them) & -1.253 & 0.213 & -5.890 & 0.000 \\
\hline Public commitment (=1 if public) & -0.076 & 0.167 & -0.460 & 0.647 \\
\hline Rewards with an inventory ( $=1$ if rewarded with an inventory) & 0.442 & 0.219 & 2.020 & 0.044 \\
\hline Monetary compensation (euros/ha/year) & 0.004 & 0.003 & 1.360 & 0.174 \\
\hline Part of Class 1 & $42.2 \%$ & & & \\
\hline Part of Class 2 & $55.4 \%$ & & & \\
\hline
\end{tabular}

\section{Discussion}

The main objective of the present study was to assess empirically the factors influencing forest owners' participation in biodiversity protection activities. Our results confirm one observation in the literature that institutions can be very important, e.g., [20] for committing to protection measures. Forest owners are more confident to protect biodiversity when the institutions are known and close to them ("Forest professionals" or" Local authorities"). So, making a commitment with forest professionals is much more likely than with the administration and consequently, the demand for economic compensation will be lower. The administration (the "prefecture") is traditionally the contract authority when French forest owners make contracts for Natura2000 areas, and this may be one of the explanations for the modest participation in these schemes by private owners $[10,31,34]$. Confidence and knowledge of their forest are the underlying determinants of the preferences for institutions according to the owners' own statements. That trust is an important determinant of preferences for policies and influences the implementation of regulations is well-established in the literature, e.g., $[35,36]$.

We also tested to which degree monetary compensation could lead to crowding out. We found that making a commitment public did not have a statistically negative effect on the utility of obtaining monetary compensation corresponding to the results of the reputational crowding-out test in [31], where social motives seem not to lessen the effect of economic incentives. However, we did find that for some forest owners, making the commitment public has a positive impact on the probability of commitment, in particular in the treatment where the forest owner is told that they are the first to conclude a contract in the neighborhood. It has previously been shown that information about other landowners' behavior can influence farmers' adoption of environmental measures [37].

The results show clearly that there is a significant heterogeneity among forest owners' preferences for commitment. While, in average, making the commitment public had no significant effect, we find for an important group of owners, making the commitment 
public may increase participation while for others it had no statistically significantly effect. In a choice experiment with farmers reported in [13], the authors find that, on average, a publicity notice of the participation in an agri-environmental scheme increases the choice of participation and they show that this fact can be used to design more cost efficient schemes. The results show also that there is a class of forest owners where participation is not conditioned on compensation. In particular if the commitments are with forest professionals or local authorities, they may even have willingness-to-pay for participation in a contract. This may be considered surprising and could be associated with the hypothetical nature of the choice experiment. However, we find in our followup questions that a significant share of the sample indicates that they don't consider the biodiversity protection as costly and that it is a moral obligation to protect biodiversity. This may explain that forest owners may not necessarily demand compensation for participation in biodiversity protection. This is confirmed by [12], finding that timber production is only the main objective for about half of the French private forest owners. We also find that the importance of compensation varies between owners, including the relative preferences for monetary and non-monetary compensation. While only a small fraction of the owners are not sensitive to monetary compensation, a larger fraction (42\%) does not consider the non-monetary compensation (a free inventory of the forest).

About $20 \%$ of the forest owners in the survey would not make a commitment, even with the highest monetary compensation of 125 euros/ha/year for the proposed measures. They do not consider it possible to implement any of the proposed measures in their forest (keeping dead wood or large trees on their plot) and they refuse them regardless of the commitment characteristics. Our main hypothesis is that this is due to some principal aversion to making a commitment. One of the main reasons stated by the respondents for never choosing a program was that they want to remain in control in their forest, which corresponds the results in [34], finding that the wish to "be in control" is an important reason for the non-adoption of Natura2000 protection measures.

The type of protection action proposed affects the probability of commitment. The measure of maintaining large trees in the stand is more favorable to commitment. Owners are more likely to be involved in this action and need less compensation. This may correspond to a lower opportunity cost for them. Here, it is important to note that the interviewed forest owners may self-select according to the management action which has the lowest opportunity cost for them. Therefore, our estimation of the demand for compensation for implementing a given action is not representative for the whole sample of forest owners but a conservative estimate.

With the follow-up questions, we obtain some insights concerning the result of the choice experiment (e.g., lack of confidence explains aversion against committing with the administration). However, we also recognize that a more comprehensive understanding of the motives underlying the choices of alternatives in the choice experiment or the understanding of real forest management decisions in the field could benefit from in-depth interviews and sociological approaches. For example, applying qualitative interviews to analyze the choice of agroforestry practices $[23,36]$ and choices of tree species in Southern Sweden [33], it is shown that Bourdieu's concept of habitus is a powerful framework for understand landowners' choices. Furthermore, future research that takes a more integrated approach that considers both economic, biophysical, and sociocultural dimensions could contribute to consolidating the insights from the present study, as recommend by NietoRomero et al. [1] in their study of ecosystem service provision. An important lesson is also that the design of PES schemes should involve stakeholders and use a bottom-up approach to ensure that institutional barriers will result in low adoption rate and policy failure.

One potential limitation of the study is that it is based on hypothetical choices, and one can ask if such choices are transferable to the real choices of commitments. This should be investigated further through, e.g., field experiments, though challenged by ethical and legal constraints of exposing different groups of forest owners to different policy treatments. The rather low sample size reduced the statistical power of our test for crowding out effects 
of monetary compensation. Therefore, while we did not statistically identify a negative effect of monetary compensation on the intrinsic motivation or social motivation to protect biodiversity, we cannot conclude that this effect is not present. A more extensive survey should be carried out.

\section{Conclusions}

The present study has shown that institutional factors are very important for forest owners' commitments to biodiversity protection in their forest. A key question concerning the design of voluntary protection schemes involves the careful choice of the scheme authority. Organizations that forest owners trust and have local knowledge of their forests facilitate forest owners' commitment and will consequently increase the cost-effectiveness of the scheme. We find that social motivation (reputation) is important for commitment as about one half of the forest owners are more likely to make a commitment when it is public and, in particular, if they know that they are the first to make a commitment in their neighborhood. Intrinsic motivation is also an important determinant as the majority of the owners state that it is a moral obligation to protect biodiversity. Besides the importance of the choice of institutions, the main lesson is that voluntary biodiversity protection schemes need to account for the different types of forest owners, namely owners who are intrinsically motivated and would participate without demand for compensation, owners who can be influenced through nudges, e.g., making commitments public, and owners for whom non-participation is a matter of principle. It is important that policy makers recognize the diversity of forest owners and adapt policies to this reality, e.g., by applying more than one incentive type.

Author Contributions: Funding acquisition: F.d.M., A.S. Conceptualization, J.A., A.S., F.d.M., P.P. and M.B.; Data curation, J.A.; Formal analysis, J.A. and A.S.; Investigation, J.A., F.d.M., P.P., M.B., C.M., A.S. Methodology, J.A., A.S. and P.P.; Project administration, A.S. and F.d.M.; Resources, F.d.M. and C.M.; Software, J.A.; Supervision, J.A., A.S.; Validation, J.A., A.S.; writing-original draft preparation: J.A., A.S.; writing-review and editing, J.A., A.S. All authors have read and agreed to the published version of the manuscript.

Funding: BGF programme "Biodiversity, forest management and public policy" coordinated by GIP ECOFOR (2014-2018). Ministry of Ecology, Sustainable development and Energy with the support of the Ministry of agriculture.

Institutional Review Board Statement: Ethical review and approval were waived for this study, due to the fact that all the agreements to survey forest owners have been managed by the Parc Naturel des Vosges du Nord.

Informed Consent Statement: Informed consent was obtained from all subjects involved in the study.

Data Availability Statement: Data from the forest owner survey should be requested from the authors.

Conflicts of Interest: The authors declare no conflict of interest.

\section{References}

1. Peterson, J.M.; Smith, C.M.; Leatherman, J.C.; Hendricks, N.; Fox, J.A. Transaction Costs in Payment for Environmental Service Contracts. Am. J. Agric. Econ. 2014, 97, 219-238. [CrossRef]

2. Hanley, N.; Banerjee, S.; Lennox, G.D.; Armsworth, P. How should we incentivize private landowners to 'produce' more biodiversity? Oxf. Rev. Econ. Policy 2012, 28, 93-113. [CrossRef]

3. Vizzarri, M.; Tognetti, R.; Marchetti, M. Forest Ecosystem Services: Issues and Challenges for Biodiversity, Conservation, and Management in Italy. Forests 2015, 6, 1810-1838. [CrossRef]

4. Nieto-Romero, M.; Oteros-Rozas, E.; González, J.A.; Martín-López, B. Exploring the knowledge landscape of eco-system services assessments in Mediterranean agroecosystems: Insights for future research. Environ. Sci. Policy 2014, 37, 121-133. [CrossRef]

5. Koulelis, P.; Solomou, A.; Fassouli, V. Sustainability Constraints in Greece. Focusing on Forest Management and Biodiversity. 2020. Available online: https://www.researchgate.net/profile/Panagiotis-Koulelis/publication/346630199_Sustainability_ Constraints_in_Greece_Focusing_on_Forest_Management_and_Biodiversity/links/5fe1ca33299bf1408833704d/SustainabilityConstraints-in-Greece-Focusing-on-Forest-Management-and-Biodiversity.pdfBiodiversity.pdf (accessed on 21 June 2021). 
6. Börner, J.; Baylis, K.; Corbera, E.; Ezzine-De-Blas, D.; Honey-Rosés, J.; Persson, U.M.; Wunder, S. The Effectiveness of Payments for Environmental Services. World Dev. 2017, 96, 359-374. [CrossRef]

7. Engel, S.; Pagiola, S.; Wunder, S. Designing payments for environmental services in theory and practice: An overview of the issues. Ecol. Econ. 2008, 65, 663-674. [CrossRef]

8. Wunder, S. Revisiting the concept of payments for environmental services. Ecol. Econ. 2015, 117, 234-243. [CrossRef]

9. Wunder, S.; Brouwer, R.; Engel, S.; Ezzine-De-Blas, D.; Muradian, R.; Pascual, U.; Pinto, R. From principles to practice in paying for nature's services. Nat. Sustain. 2018, 1, 145-150. [CrossRef]

10. Hily, E.; Garcia, S.; Stenger, A.; Tu, G. Assessing the cost-effectiveness of a biodiversity conservation policy: A bio-econometric analysis of Natura 2000 contracts in forest. Ecol. Econ. 2015, 119, 197-208. [CrossRef]

11. Miljand, M.; Bjärstig, T.; Eckerberg, K.; Primmer, E.; Sandström, C. Voluntary Agreements to Protect Private Forests-A Realist Review. For. Policy Econ. 2021, 128, 102457. [CrossRef]

12. Petucco, C.; Abildtrup, J.; Stenger-Letheux, A. Influences of nonindustrial private forest landowners' management priorities on the timber harvest decision-A case study in France. J. For. Econ. 2015, 21, 152-166. [CrossRef]

13. Banerjee, P.; Pal, R.; Wossink, A.; Asher, J. Heterogeneity in Farmers' Social Preferences and the Design of Green Payment Schemes. Environ. Resour. Econ. 2021, 78, 201-226. [CrossRef]

14. Banerjee, P.; Shogren, J.F. Material interests, moral reputation, and crowding out species protection on private land. J. Environ. Econ. Manag. 2012, 63, 137-149. [CrossRef]

15. Bénabou, R.; Tirole, J. Incentives and Prosocial Behavior. Am. Econ. Rev. 2006, 96, 1652-1678. [CrossRef]

16. Andreoni, J. Giving with Impure Altruism: Applications to Charity and Ricardian Equivalence. J. Political Econ. 1989, 97, 1447-1458. [CrossRef]

17. Falk, A.; Fehr, E.; Fischbacher, U. On the Nature of Fair Behavior. Econ. Inq. 2003, 41, 20-26. [CrossRef]

18. Fehr, E.; Schmidt, K.M. A theory of fairness, competition, and cooperation. Q. J. Econ. 1999, 114, 817-868. [CrossRef]

19. Reeson, A.; Tisdell, J. Institutions, motivations and public goods: An experimental test of motivational crowding. J. Econ. Behav. Organ. 2008, 68, 273-281. [CrossRef]

20. Frey, B.; Oberholzer-Gee, F. The Cost of Price Incentives: An Empirical Analysis of Motivation Crowding Out. Am. Econ. Rev. 1997, 87, 746-755. Available online: http:/ / www.jstor.org/stable/2951373 (accessed on 16 June 2021).

21. Gneezy, U.; Rustichini, A. A Fine is a Price. J. Leg. Stud. 2000, 29, 1. Available online: https:/ / ssrn.com/abstract=180117 (accessed on 16 June 2021). [CrossRef]

22. Danley, B.; Bjärstig, T.; Sandström, C. At the limit of volunteerism? Swedish family forest owners and two policy strategies to increase forest biodiversity. Land Use Policy 2021, 105, 105403. [CrossRef]

23. Rode, J.; Gómez-Baggethun, E.; Krause, T. Motivation crowding by economic incentives in conservation policy: A review of the empirical evidence. Ecol. Econ. 2015, 117, 270-282. [CrossRef]

24. Chervier, C.; Le Velly, G.; Ezzine-De-Blas, D. When the Implementation of Payments for Biodiversity Conservation Leads to Motivation Crowding-out: A Case Study from the Cardamoms Forests, Cambodia. Ecol. Econ. 2019, 156, 499-510. [CrossRef]

25. Primmer, E.; Paloniemi, R.; Similä, J.; Tainio, A. Forest owner perceptions of institutions and voluntary contracting for biodiversity conservation: Not crowding out but staying out. Ecol. Econ. 2014, 103, 1-10. [CrossRef]

26. Kerr, J.; Vardhan, M.; Jindal, R. Prosocial behavior and incentives: Evidence from field experiments in rural Mexico and Tanzania. Ecol. Econ. 2012, 73, 220-227. [CrossRef]

27. Broch, S.W.; Vedel, S.E. Using Choice Experiments to Investigate the Policy Relevance of Heterogeneity in Farmer AgriEnvironmental Contract Preferences. Environ. Resour. Econ. 2011, 51, 561-581. [CrossRef]

28. Greiner, R.; Bliemer, M.; Ballweg, J. Design considerations of a choice experiment to estimate likely participation by north Australian pastoralists in contractual biodiversity conservation. J. Choice Model. 2014, 10, 34-45. [CrossRef]

29. Vaissière, A.-C.; Tardieu, L.; Quétier, F.; Roussel, S. Preferences for biodiversity offset contracts on arable land: A choice experiment study with farmers. Eur. Rev. Agric. Econ. 2018, 45, 553-582. [CrossRef]

30. Vedel, S.E.; Jacobsen, J.B.; Thorsen, B.J. Forest owners' willingness to accept contracts for ecosystem service provision is sensitive to additionality. Ecol. Econ. 2015, 113, 15-24. [CrossRef]

31. Polome, P. Private forest owners motivations for adopting biodiversity-related protection programs. J. Environ. Manag. 2016, 183, 212-219. [CrossRef]

32. Scarpa, R.; Rose, J.M. Design efficiency for non-market valuation with choice modelling: How to measure it, what to report and why*. Aust. J. Agric. Resour. Econ. 2008, 52, 253-282. [CrossRef]

33. McFadden, D.L. Conditional Logit Analysis of Qualitative Choice Behavior. In Frontiers in Econometrics; Zarembka, P., Ed.; Academic Press: New York, NY, USA, 1974; pp. 105-142.

34. Polome, P.; Michel, C. Why Are Private Forest Owners Not Adopting Natura 2000? A Survey of Motivations; Working paper GATE No. 1721; SSRN: Lyon, France, 2017. [CrossRef]

35. Oehlmann, M.; Meyerhoff, J. Stated preferences towards renewable energy alternatives in Germany-Do the consequentiality of the survey and trust in institutions matter? J. Environ. Econ. Policy 2016, 6, 1-16. [CrossRef]

36. Vatn, A. Rationality, institutions and environmental policy. Ecol. Econ. 2005, 55, 203-217. [CrossRef]

37. Kuhfuss, L.; Préget, R.; Thoyer, S.; Hanley, N.; LE Coent, P.; Désolé, M. Nudges, Social Norms, and Permanence in Agrienvironmental Schemes. Land Econ. 2016, 92, 641-655. [CrossRef] 